\title{
Notes on the Text and Translation
}

The translation presented here under Sade's working title "Voyage d'Italie" (Journey to Italy) was a project in progress when Sade abandoned it. Chapters on Florence, Rome, the environs of Rome, and for the better part, Naples had been drafted, edited, and copied out by his valet, La Jeunesse. Chapters on the environs of Naples, which include some of the most interesting material in the entire manuscript, and on the route from Naples to Rome (or vice versa) had also been drafted, but they are fragmentary and riddled with errors. We know that La Jeunesse was still copying out the manuscript with the aid of Sade's wife, Renée-Pélagie de Montreuil, in early 1779. At this point, Sade despondently claimed there was no urgency to the business, as he would only need the work after his release from prison. This release Sade thought imminent, unaware that he still had a decade to go before the Revolution would, at least temporarily, secure his liberty. Renée-Pélagie encouraged her husband to forge ahead and not lose heart. Her uxorial confidence appears to have been misplaced; the project languished.

The first French publication of Sade's manuscript, Voyage d'Italie, edited by Gilbert Lely and George Daumas, appeared only in 1967. It comprised just the fully drafted chapters on Florence, Rome, the environs of Rome, and most of the chapter on Naples. ${ }^{1}$ The source text for my translation, Journey to Italy, is the first volume of Maurice Lever's Voyage d'Italie from 1995, which presents all of the material that the Marquis de Sade had gathered and redacted for his proposed book on what he saw and experienced in Italy, along with his exploratory drafts, fragments, summations, and selected excerpts from published sources that he was using for context and comparison with his own observations. It also includes correspondence addressed to Sade, both during but more especially after his trip, related to his travels in Italy and to the developing manuscript. Lever's second volume is a collection of sketches for the work by Jean-Baptiste Tierce, artist and Sade's companion and guide in Naples and its vicinity; these are not included here. ${ }^{2}$ I have also not translated Lever's introduction, and I have greatly expanded the explanatory and critical notes, which are almost entirely original.

These notes are numerous and function in various ways: they identify and clarify sometimes obscure geographical, historical, literary, and artistic mentions; they provide elucidations and comparisons from other Italian travel guides; and they give a thorough account 
of Sade's many textual sources. These sources include, certainly, travel writers such as Jérôme Richard and Joseph Jérôme Le François de Lalande, both of whom Sade resorts to frequently, alongside many others. Sade also delves into numerous political and ecclesiastical histories relevant to his voyage, not to mention scientific publications, periodicals, and much more. Unsurprisingly, he turns to biographical and geographical dictionaries and similar reference works. Less expectedly perhaps, he demonstrates a broad and exceptionally expansive commitment to classical learning, highlighting historians and biographers Livy and Suetonius, above all. With this critical apparatus, I have sought to provide a rich and deep understanding not only of Sade's text, but also of its diverse contexts. Among other things, I hope this apparatus reveals just how enthusiastic and engaged an amateur scholar the Marquis de Sade was and helps readers today grasp the workings and development of a truly curious mind. Indeed, although the sources in the manuscript presented herein are mainly focused on the project to provide a philosophical Italian guidebook, what emerges simultaneously is a panorama of the pre-Revolutionary publishing business through the eyes of an au courant and avid, if idiosyncratic, bibliophile and intellectual. Let me add that unless otherwise made obvious, any translations in this volume that are from other non-English sources are my own.

Sade's sentences in the manuscript are occasionally convoluted and unclear; the later chapters and dossiers are unpolished and frequently disjointed. On the whole, I have opted for silent correction of solecisms while trying to preserve some of the syntactic flavour of the source texts. On rare occasions, I have simply had to render what Sade seems to have had in mind. Evident errors and lacunae are pointed out in the explanatory notes. When an item is glossed in brackets, I have used "i.e." to indicate a simple clarification and "viz." to indicate a correction. Sade usually but not always gallicizes Italian place names and just as often people's names, too. To provide the flavour of the original, I have followed his practice for place names by anglicizing them, although Italian references are provided in brackets the first time they appear for ease of identification. On occasion, I have also provided Sade's original French in brackets, where a particular word choice or turn of phrase is illuminating or amusing. For people's names, I have generally adhered to Italian forms, except where English or Latin forms are already common, as is the case, for example, with the adopted names of popes, European royalty, and Roman emperors and writers. The reader will encounter neither Tibère nor Tiberio, but the familiar Tiberius. For the names of artists, I follow Sade's usually abbreviated forms, common at the time, although I provide entire names or glosses of bynames in brackets the first time a particular artist's name appears in a given chapter. I have not followed this practice when abbreviated forms are still common - not Michelangelo Buonarroti, except in those cases when Sade himself so styles the man, let alone Michelangelo di Lodovico Buonarroti Simoni, but simply Michelangelo.

Some French words or terms really do not work well translated. For example, abbé can mean either priest or abbot. Although many of Sade's sources, interestingly enough, were abbés, very few were abbots, that is, heads of monasteries. Notably, Jérôme Richard, who Sade mentions again and again, was an abbé though not an abbot. Sade's uncle, JacquesFrançois-Paul-Aldonce de Sade, who wrote on Petrarch, served as a libertine role model for his nephew, and went by abbé de Sade, was in fact, an abbot - or, more precisely, a commendatory abbot - of the Abbaye Saint-Léger d'Ébreuil in Auvergne.

The French parlement, although the origin of "parliament" in English, does not mean a legislative body and so cannot be translated as equivalent. The thirteen parlements in preRevolutionary France, of which the most powerful was located in Paris, were the highest 
law courts and courts of appeal in that country, though responsible also for registering royal laws and edicts. Thus, in my translation parlement will remain as in French. The reader will also come across obsolete or otherwise dated meanings and usages. Appartement, or apartment, for example, is simply the equivalent of a room within a palace or other large residence and never has the modern sense of a set of rooms composing a private dwelling within a building, or in British usage, a "flat." In the plural, the term usually indicates a suite of rooms, and I have often translated it as such. Appartements were often private quarters or set apart, although one might also speak of apartments for receiving guests. One of the pleasures of reading the Journey to Italy is getting a glimpse into the different manners that residential life, particularly of the nobility, was spatially and culturally organized. For his part, Sade frequently comments on Italian mores in this regard.

Astute readers will note that although he occasionally uses the designation "basilica" and seems to understand that the term indicates a church granted particular duties and privileges, Sade will almost invariably simply call such a structure a "church" or even a "cathedral." This is not an idiosyncrasy, and Sade's fellow French travel writers such as Jérôme Richard and François Maximilien Misson likewise write of the Église de St Pierre de Rome, that is, Church of Saint Peter's in Rome and not the Basilica. I have maintained the custom of the era in this regard, but occasionally indicate in brackets or in a note the current usage and correct designation.

Donatien Alphonse François, Marquis de Sade's initial conception was a guide to the sights and mores of Italy in epistolary form. Correspondence was a key feature of aristocratic and educated life in the eighteenth century and one that famously shaped the development of the sentimental novel, where the epistolary format enables thick description of interiority. Travel writers at the time also frequently turned to the simulacrum of letters as an understandable means of organizing their works. ${ }^{3}$ For most of the relatively polished portion of the manuscript, Sade addresses as his implied reader a certain "Madame Countess." This was an artifice that he had used for his first foray into travel writing, a considerably shorter work describing his voyage to the Low Countries and the cities of Brussels, Rotterdam, Amsterdam, and Utrecht in the last months of $1769 .{ }^{4}$ Here, about halfway through the chapter on Naples, Sade inconsistently begins to address a "dear count" rather than "countess." The shift seems to indicate a change in plans or, more precisely, an increased seriousness of purpose. The letters will now be even more philosophical, less conversational. In notes related to the project, Sade tells himself that "this Voyage will be presented as a letter by a philosopher who has travelled, who imparts his reflections to a friend who wants to make the same voyage as he." He elsewhere reminds himself that a traveller - by which he means a travel writer - "must speak little of himself," personal anecdotes detract from the goal of a good guide, which is to familiarize the reader with "the spirit [esprit] or the mores of the nation through which he travels." Both of these instructions to the writer bespeak this increased seriousness. Yet Sade never settled on a final form, and although he may have intended to pursue a more muscular philosophical tone and to expunge the conversational, the manuscript and its attendant documents reveal a text and an author in the making.

All parts of Journey to Italy are marked up with considerable marginalia and notes these are provided in the footnotes and indicated as such - further evidence of the evolving nature of the work.

Sade is here experimenting with voice, rhetoric, genre, and, indeed, basic organization. At one point, for example, he considers keeping to the epistolary format, but instead of dedicating each letter to a major urban area or its environs, subdividing these by letter 
into significant categories. Thus, Rome would be divided into separate letters on arrival and on churches, then a letter on palaces, on country estates and their surrounding areas, followed by mores and customs. The dossiers suggest that a more treatise-like project was tempting him as well, which would have included a thorough accounting of Italy's history, its current governance and mores, and plans for reform. This ambitious project eventually transformed into a preface - that was never drafted. All the same, Sade took copious notes on ancient Roman history, as well as on medieval Italian history, and he kept up his correspondence with his contacts in Italy with the aim of fleshing out details and adding intellectual heft. Doctors Mesny and Iberti were of particular help in this regard, and their letters to Sade are included among the relevant correspondence that makes up the final chapter of the present volume. Sade's prodding of Iberti for licentious archival material from ancient and likely papal history may indicate a plan to write a separate work, essentially on libertinism from a philosophical viewpoint, or he may have hoped to fold this material into the Journey to Italy. The Marquis de Sade may have abandoned his Italian project, yet his subsequent writings amply attest that his preparations and research for it were hardly a dead loss for him. For us, the manuscript translated here provides not only insight into the formation and evolution of its notorious author, but also an entrée into the multifaceted world of preRevolutionary life and letters, along with a vivid, meandering, standard, quirky, trenchant, and entertaining account of how and why Italian art, culture, history, and geography played such a prominent role therein.

\section{NOTES}

1 Sade, Voyage d'Italie: précédé des Premières æuvres; suivi de Opuscules sur le théâtre, eds. Gilbert Lely and Georges Daumas (Paris: Tchou, 1967).

2 Sade, Voyage d'Italie, ed. Maurice Lever (Paris: Fayard, 1995).

3 For example, the anonymously published [Jean-Baptiste-Marie Guidi] Lettres contentant un journal d'un voyage fait à Rome en 1773 [Letters containing a journal of a voyage made to Rome in 1773] (Geneva, 1783). It begins with the assertions that there are few original guides to Italy and that this one has a straightforward genealogy: "son of Lalande, who was son of Richard, who was son of Misson, and so forth" (1:xi).

4 See Schaeffer, The Marquis de Sade: A Life (New York: Alfred A. Knopf, 1999), 105-6. 